\title{
PENGARUH STRUKTUR MODAL DAN UKURAN PERUSAHAAN TERHADAP NILAI PERUSAHAAN PADA PERUSAHAAN MANUFAKTUR SEKTOR INDUSTRI MAKANAN DAN MINUMAN YANG TERDAFTAR DI BURSA EFEK INDONESIA (BEI)
}

\author{
FACHTURAHMAN TRIATMAJA \\ M. FAISAL \\ HUSNAH \\ Prodi Manajemen, Fakultas Ekonomi, Universitas Tadulako \\ fachturtriatmaja@gmail.com
}

\begin{abstract}
This study aims to determine and analyze the influence of capital structure and the size of the company on the company values in manufacturing companies of food and beverage industry sectors listed on the Indonesia Stock Exchange (BEI). The sample in this study consists of 11 companies that selected by purposive sampling technique. Method of data analysis is multiple linear regression using SPSS version 16.0. The results show that both independent variables simultaneously have positive and significant influence on value of the company with sig-F of $0.093 \leq \alpha 0.10$ at confidence level of $90 \%$. The t-test shows that the capital structure significantly has negative influence on the value of the company with sig-t of $X 1=0.032 \leq \alpha$ of 0.10 and beta value of -0882 . While the company size has non-significant influence on the value of the company with sig-t $X 2=0.787 \geq \alpha$ of 0.10 with $R^{2}$ values of 0.052 or $5.2 \%$. Both independent variables studied simultaneously influence the dependent variable (enterprise value), while the remaining $94.8 \%$ is influenced by other variables that are not studied.
\end{abstract}

Keywords: capital structure, company size, company value.

\section{Abstrak}

Penelitian ini bertujuan untuk mengetahui dan menganalisis pengaruh struktur modal dan ukuran perusahaan terhadap nilai perusahaan di sektor industri makanan dan minuman manufaktur yang terdaftar di Bursa Efek Indonesia (BEI). Sampel dalam penelitian ini sebanyak 11 perusahaan diambil dengan metode purposive sampling. Metode analisis data dilakukan dengan menggunakan regresi linier berganda dengan menggunakan SPSS versi 16.0. Hasil penelitian menunjukkan bahwa kedua variabel bebas yang dipelajari secara simultan terbukti berpengaruh positif dan signifikan terhadap variabel terikatnya yaitu nilai perusahaan dengan sig-F sebesar $0,093 \leq \alpha 0,10$ pada tingkat kepercayaan $90 \%$. Kemudian melalui uji-t menunjukkan bahwa struktur modal dari efek negatif yang signifikan terhadap nilai perusahaan dengan sig-t X1 $=0,032 \leq \alpha$ sebesar 0,10 dan nilai beta -0882 . Sedangkan ukuran perusahaan tidak berpengaruh signifikan terhadap nilai perusahaan dengan sig-t X2 = $0,787 \geq \alpha 0,10$. Nilai R2 0,052 atau 5,2\% sehingga kedua variabel independen yang dipelajari secara simultan mempengaruhi variabel dependen (nilai perusahaan), sedangkan sisanya 94,8\% dipengaruhi oleh variabel lain yang tidak diteliti.

Kata kunci: Struktur Modal, Ukuran Perusahaan, Nilai Perusahaan.

\section{PENDAhUluan}

\section{Latar Belakang Penelitian}

Era globalisasi saat ini, perusahaan - perusahaan mengalami persaingan yang begitu ketat. Dalam menghadapi persaingan, bagi setiap perusahaan harus meningkatkan kinerjanya agar dapat bersaing dengan perusahaan yang lain. Perusahaan dibentuk harus mempunyai tujuan yang jelas dan terarah, yaitu memakmurkan pemilik perusahaan atau pemilik saham, memaksimalkan nilai perusahaan yang tercermin dari harga sahamnya dan harus mencapai keuntungan atau profit yang maksimal. 
Perusahaan tidak mungkin dapat memaksimumkan kemakmuran pemegang saham dengan mengabaikan kepentingan pihak - pihak lain. Oleh sebab itu tujuan memaksimumkan kemakmuran pemegang saham dapat dipandang sebagai tujuan akhir yang harus dicapai oleh manajer keuangan perusahaan (Sartono, 2012).

Nilai perusahaan sangat penting karena mencerminkan kinerja perusahaan yang dapat mempengaruhi persepsi investor terhadap perusahaan. Harga pasar saham juga menunjukkan nilai perusahaan. Misalkan sebuah perusahaan menjual $100 \%$ sahamnya dipasar modal, maka nilai perusahaan adalah sebesar kapitalisasi saham yang beredar, tentunya dengan asumsi pasar modal yang efisien. Dengan demikian apabila harga pasar saham meningkat berarti nilai perusahaan juga meningkat. Tujuan untuk memaksimumkan nilai perusahaan juga memiliki beberapa keuntungan terutama dalam pembelian perusahaan dan penggabungan perusahaan atau merger. Bagi perusahaan yang go public, akan lebih mudah mengukur nilai perusahaan dibanding dengan perusahaan yang tidak go public. Nilai perusahaan yang tidak go public, dapat diukur dengan harga jual seandainya perusahaan tersebut akan dijual yang tidak akan mencerminkan nilai aset perusahaan tetapi meliputi tingkat risiko usaha, prospek perusahaan, manajemen, lingkungan usaha dan faktor-faktor lainnya (Sartono, 2012).

Risiko yang makin tinggi cenderung menurunkan harga saham, tetapi meningkatnya tingkat pengembalian yang diharapkan (expected rate of return) akan menaikkan harga saham tersebut. Struktur modal yang optimal harus berada pada keseimbangan antara risiko dan pengembalian yang memaksimumkan harga saham (Brigham \& Houston, 2001). Dalam mengambil keputusan keuangan, manajer keuangan perlu menentukan tujuan yang harus dicapai. Keputusan keuangan yang tepat dapat memaksimumkan nilai perusahaan sehingga mampu meningkatkan kemakmuran pemilik perusahaan. Menurut Jensen (2001), dalam Dewi \& Wirajaya (2013), untuk memaksimalkan nilai perusahaan tidak hanya nilai ekuitas saja yang diperhatikan, tetapi juga sumber keuangan seperti hutang maupun saham preferen. Menurut Fama (1978), dalam Dewi dan Wirajaya (2013), nilai perusahaan dapat dilihat dari harga sahamnya. Harga saham terbentuk atas permintaan dan penawaran investor, sehingga harga saham tersebut dapat dijadikan proksi nilai perusahaan.

Nilai perusahaan dapat pula dipengaruhi oleh ukuran perusahaan. Ukuran perusahaan dianggap mampu mempengaruhi nilai perusahaan, karena semakin besar ukuran atau skala perusahaan maka akan semakin mudah perusahaan memperoleh sumber pendanaan baik eksternal maupun internal (Prasetyorini, 2013). Kestabilan perusahaan akan menarik investor untuk memiliki saham perusahaan. Kondisi ini akan menaikan harga saham perusahaan di pasar modal. Adanya kenaikan harga saham akan menyebabkan naiknya nilai perusahaan. Sebaliknya, jika ukuran perusahaan kecil, investor cenderung tidak akan tertarik untuk menanamkan modalnya di perusaahaan tersebut, sehingga nilai perusahaan itu akan semakin turun dan berdampak negatif pada perusahaan tersebut.

Banyak penelitian yang dilakukan mengenai struktur modal, ukuran perusahaan dan nilai perusahaan. Penelitian dari Prasetia, dkk., (2014), menunjukkan bahwa struktur modal tidak berpengaruh terhadap nilai perusahaan sedangkan ukuran perusahaan berpengaruh terhadap nilai perusahaan. Hasil penelitian dari Dewi \& Wirajaya (2013), menunjukan bahwa struktur modal berpengaruh terhadap nilai perusahaan dan ukuran perusahaan tidak berpengaruh pada nilai perusahaan. Hasil penelitian dari Prasetyorini (2013), menunjukkan ukuran perusahaan berpengaruh terhadap nilai perusahaan. Pada penelitian Moniaga, (2013), menunjukkan bahwa struktur modal berpengaruh terhadap nilai perusahaan. Penelitian dari Pratiwi, dkk., (2016), menunjukkan bahwa struktur modal dan ukuran perusahaan mempunyai pengaruh terhadap nilai perusahaan.

Berdasarkan hasil dari penelitian diatas terdapat perbedaan, sehingga membuat peneliti ingin meneliti kembali tentang Pengaruh Struktur Modal dan Ukuran Perusahaan Terhadap Nilai Perusahaan dengan waktu periode penelitian yang berbeda yaitu tahun 2010-2014 dan di industri yang berbeda yaitu pada perusahaan manufaktur sektor industri makanan dan minuman.

Obyek penelitian ini adalah perusahaan manufaktur sektor industri makanan dan minuman yang terdaftar di Bursa Efek Indonesia dengan alasan bahwa pertumbuhan industri makanan dan minuman pada tahun 2014 mencapai 9.54\%. Pada tahun 2013, kontribusi industri makanan dan minuman terhadap produk domestik bruto (PDB) sektor industri non migas mencapai $29.01 \%$. Sedangkan pada tahun 2014, industri makanan dan minuman berkonstribusi terhadap produk domestik bruto (PDB) sektor industri non migas mencapai 29,77\% (Sumber: http://mix.co.id). Hal ini 
menunjukkan bahwa industri makanan dan minuman sudah cukup baik, namun masih perlu ada peningkatan agar dapat lebih maju lagi di masa mendatang.

\section{Permasalahan Penelitian}

Berdasarkan uraian latar belakang diatas, maka dirumuskan permasalahan penelitian yaitu :

1. Apakah Struktur Modal dan ukuran perusahaan berpengaruh terhadap nilai perusahaan pada perusahaan manufaktur sektor industri makanan dan minuman yang terdaftar di Bursa Efek Indonesia?

2. Apakah struktur modal berpengaruh terhadap nilai perusahaan pada perusahaan manufaktur sektor industri makanan dan minuman yang terdaftar di Bursa Efek Indonesia ?

3. Apakah ukuran perusahaan berpengaruh terhadap nilai perusahaan pada perusahaan manufaktur sektor industri makanan dan minuman yang terdaftar di Bursa Efek Indonesia?

\section{Tujuan Penelitian}

Sesuai dengan perumusan masalah diatas, maka tujuan dari penelitian ini adalah untuk :

1. Untuk mengetahui struktur modal dan ukuran perusahaan berpengaruh terhadap nilai perusahaan pada perusahaan manufaktur sektor industri makanan dan minuman yang terdaftar di Bursa Efek Indonesia?

2. Untuk mengetahui struktur modal berpengaruh terhadap nilai perusahaan pada perusahaan manufaktur sektor industri makanan dan minuman yang terdaftar di Bursa Efek Indonesia?

3. Untuk mengetahui ukuran perusahaan berpengaruh terhadap nilai perusahaan pada perusahaan manufaktur sektor industri makanan dan minuman yang terdaftar di Bursa Efek Indonesia?

\section{KAJIAN LITERATUR DAN PENGEMBANGAN HIPOTESIS Struktur Modal}

Husnan (2000), menyatakan struktur modal adalah perbandingan antara sumber jangka panjang yang bersifat pinjaman dan modal sendiri. Keown, dkk., (2005), dalam Prasetia, dkk., (2014), menyatakan struktur modal (capital structure) adalah perpaduan sumber dana jangka panjang longterm sources of funds yang digunakan perusahaan. Untuk mencapai tujuan perusahaan dalam memaksimalisasi kekayaan pemegang saham, manajer keuangan harus dapat menilai struktur modal dan memahami hubungannya dengan risiko, hasil atau pengembalian nilai.

\section{Rasion Profitabilitas}

Profitabilitas adalah kemampuan perusahaan dalam memperoleh laba. Para investor menanamkan saham pada perusahaan adalah untuk mendapatkan return. Semakin tinggi kemampuan perusahaan memperoleh laba, maka semakin besar return yang diharapkan investor, sehingga menjadikan nilai perusahaan menjadi lebih baik.

\section{Nilai Perusahaan (FV)}

Nilai perusahaan merupakan persepsi investor terhadap perusahaan, yang sering dikaitkan harga saham. Harga saham yang tinggi membuat nilai perusahaan juga tinggi. Harga saham merupakan harga yang terjadi pada saat saham diperdagangkan di pasar

\section{METODE PENELITIAN}

\section{Metode Pengumpulan Data}

Metode Pengumpulan data yang digunakan dalam penelitian ini adalah melalui pengumpulan data sekunder atau data tidak langsung. Data diperoleh dari situs http:// www.idx.co.id, untuk laporan keuangan perusahaan, khususnya neraca dan laporan laba rugi perusahaan yang tergabung dalam kelompok perusahaan manufaktur sektor industri makanan dan minuman yang terdaftar di Bursa Efek Indonesia (BEI) pada tahun 2010-2014. 
Metode Analisis

Analisis Regresi Berganda

Metode analisis data yang digunakan dalam penelitian ini adalah analisis regresi berganda untuk menguji pengaruh struktur modal dan ukuran perusahaan terhdap nilai perusahaan.

\section{Uji Asumsi Klasik}

Uji asumsi klasik digunakan untuk mengetahui apakah model yang digunakan dalam regresi benar-benar menunjukkan hubungan yang signifikan dan representatif maka model yang digunakan tersebut harus memenuhi uji asumsi klasik regresi (Hidayat, 2015). Uji asumsi klasik meliputi uji normalitas, uji multikolinearitas, uji autokorelasi dan uji heteroskedastisitas.

\section{Uji Normalitas}

Menurut Ghozali, (2011), dalam Permanasari (2010), uji normalitas bertujuan untuk menguji apakah dalam model regresi, variabel terikat dan variabel bebas keduanya mempunyai distribusi normal atau tidak.

\section{Uji Multikolinearitas}

Uji multikolinearitas bertujuan untuk menguji apakah model regresi ditemukan adanya korelasi antar variabel bebas (Permanasari, 2010).

\section{Uji Autokorelasi}

Uji autokorelasi bertujuan menguji apakah model linear ada korelasi antara kesalahan pengganggu pada periode $t$ dengan kesalahan pengganggu pada periode $t-1$ (sebelumnya) (Ghozali, 2009 dalam Permanasari, 2010).

\section{Uji Heteroskedastisitas}

Uji heteroskedastisitas bertujuan untuk menguji apakah model regresi terjadi ketidaksamaan variance dari residual satu pengamatan ke pengamatan lain.

\section{Uji Hipotesis}

Uji Signifikansi Simultan (Uji Statistik F)

Uji $\mathrm{F}$ digunakan untuk menguji tingkat pengaruh variabel independen terhadap variabel dependen secara bersama - sama.

\section{Uji Signifikansi Parsial (Uji-t)}

Uji parsial dilakukan dengan statistik-t. Uji t digunakan untuk menguji apakah variabel independen secara parsial mempunyai pengaruh terhadap variabel dependen.

\section{HASIL DAN PEMBAHASAN}

\section{Deskripsi Variabel Penelitian}

Berdasarkan judul Pengaruh Struktur Modal Dan Ukuran Perusahaan Terhadap Nilai Perusahaan Pada Perusahaan Manufaktur Sektor Industri Makanan Dan Minuman Yang Terdaftar Di Bursa Efek Indonesia (BEI). Penelitian ini bertujuan untuk mengetahui seberapa besar pengaruh struktur modal dan ukuran perusahaan baik secara bersama - sama maupun secara parsial berpengaruh terhadap nilai perusahaan pada perusahaan manufaktur sektor industri makanan dan minuman yang terdaftar di bursa efek Indonesia.

\section{Perkembangan Struktur Modal Pada Perusahaan Manufaktur Sektor Industri Makanan Dan Minuman Di Bursa Efek Indonesia}

Husnan (2000), menyatakan struktur modal adalah perbandingan antara sumber jangka panjang yang bersifat pinjaman dan modal sendiri. Berikut perkembangan struktur modal perusahaan manufaktur sektor industri makanan dan minuman di bursa efek Indonesia : 
Tabel 1. Perkembangan Struktur Modal Pada Perusahaan Manufaktur Sektor Industri Makanan Dan Minuman Di Bursa Efek Indonesia Periode Penelitian 2010-2014

\begin{tabular}{|c|c|c|c|c|c|c|}
\hline \multirow[t]{2}{*}{ No } & \multirow[t]{2}{*}{ Nama Perusahaan } & \multicolumn{5}{|c|}{ Tahun } \\
\hline & & 2010 & 2011 & 2012 & 2013 & 2014 \\
\hline 1. & Akasha Wira International Tbk, PT & 2.25 & 1.51 & 0.86 & 0.67 & 0.71 \\
\hline 2. & Delta Djakarta Tbk, PT & 0.23 & 0.22 & 0.25 & 0.28 & 0.30 \\
\hline 3. & Indofood CBP Sukses Makmur Tbk, PT & 0.45 & 0.42 & 0.48 & 0.60 & 0.66 \\
\hline 4. & IndofoodSukses Makmur Tbk, PT & 1.82 & 0.70 & 0.74 & 1.04 & 1.08 \\
\hline 5. & Mayora Indah Tbk, PT & 1.21 & 1.72 & 1.71 & 1.47 & 1.51 \\
\hline 6. & Multi Bintang Indonesia Tbk, PT & 1.41 & 1.30 & 2.49 & 0.80 & 3.03 \\
\hline 7. & Nippon Indosari Corporindo Tbk, PT & 0.25 & 0.39 & 0.81 & 1.32 & 1.23 \\
\hline 8. & Sekar Laut Tbk, PT & 0.69 & 0.74 & 0.93 & 1.16 & 1.16 \\
\hline 9. & Siantar Top Tbk, PT & 0.45 & 0.91 & 1.16 & 1.12 & 1.08 \\
\hline 10. & $\begin{array}{l}\text { Ultrajaya Milk Industry and } \\
\text { Trading Company Tbk, PT }\end{array}$ & 0.55 & 0.55 & 0.44 & 0.40 & 0.29 \\
\hline 11. & $\begin{array}{l}\text { Wilmar Cahaya Indonesia Tbk, PT } \\
\text { (dh. Cahaya Kalbar Tbk, PT) }\end{array}$ & 1.75 & 1.03 & 1.22 & 1.02 & 1.39 \\
\hline & Nilai Rata - Rata & 1.00 & 0.86 & 1.01 & 0.90 & 1.13 \\
\hline & Nilai Maksimum & 2.25 & 1.72 & 2.49 & 1.47 & 3.03 \\
\hline & Nilai Minimum & 0.23 & 0.22 & 0.25 & 0.28 & 0.29 \\
\hline
\end{tabular}

Berdasarkan Tabel 1 menunjukkan bahwa struktur modal pada perusahaan manufaktur sektor industri makanan dan minuman yang terdaftar di bursa efek Indonesia periode 2010-2014 mengalami fluktuasi. Struktur modal yang optimal dapat berubah sewaktu - waktu, perubahan ini dapat mempengaruhi tingkat risiko dan biaya dari setiap jenis modal, yang pada gilirannya mengubah biaya modal rata - rata tertimbang. Perubahan ini juga akan mempengaruhi keputusan penganggaran modal yang pada akhirnya mempengaruhi harga saham perusahaan. Karena itu, meskipun perusahaan perusahaan berada dalam industri yang sama, seringkali mempunyai struktur modal yang sangat berbeda (Brigham \& Houston, 2001).

PT. Multi Bintang Indonesia Tbk. mempunyai struktur modal tertinggi yaitu 3.03 dan PT. Delta Djakarta Tbk. mempunyai struktur modal terendah yaitu 0.22. PT. Multi Bintang Indonesia Tbk. mempunyai struktur modal tertinggi dikarenakan perusahaan menggunakan hutang lebih besar dibanding modal sendiri, sehingga risiko yang akan dihadapi perusahaan akan semakin besar. Perusahaan yang mempunyai struktur modal yang terlalu tinggi, sangatlah berisiko. Karena jika di dalam sebuah perusahaan mempunyai struktur modal terlalu tinggi dana yang tersedia akan menganggur dan berpeluang digunakan untuk keperluan diluar kepentingan perusahaan sehingga berdampak pada masa depan perusahaan. Begitupun sebaliknya, PT. Delta Djakarta Tbk. mempunyai struktur modal terendah. Hal tersebut dapat disebabkan perusahaan menggunakan sumber modalnya lebih besar berasal dari modal sendiri dibandingkan dari hutang, sehingga risiko yang dihadapi pun jauh lebih kecil. Struktur modal yang terlalu kecil dan jauh di bawah nilai optimal juga tidak baik bagi suatu perusahaan. Karena jika jumlah modalnya terlalu kecil akan menghambat operasional perusahaan. Perusahaan akan kesulitan untuk mengembangkan inovasi dalam mengembangkan produk yang dihasilkannya. Sehingga perusahaan tersebut akan tertinggal dengan perusahaan pesaingnya dan berdampak buruk bagi perusahaan tersebut. Bagi perusahaan yang mempunyai total hutang lebih tinggi dari pada modal sendiri akan memiliki pendapatan yang berbeda dibanding perusahaan yang memilih menggunakan modal sendiri dari pada menggunakan hutang. Perusahaan yang memilih menggunakan hutang, pendapat yang diperoleh akan dikurangi dengan biaya bunga serta hutang yang dimiliki. Sedangkan perusahaan yang memilih menggunakan modal sendiri pendapatan yang diperoleh akan dikurangi dengan biaya pajak. Sehingga pendapatan tertinggi akan diperoleh perusahaan menggunakan modal sendiri dibanding menggunakan hutang. 


\section{Perkembangan Ukuran Perusahaan Pada Perusahaan Manufaktur Sektor Industri Makanan Dan Minuman Di Bursa Efek Indonesia}

Menurut Prasetyorini (2013), ukuran perusahaan adalah suatu skala dimana dapat diklasifikasikan besar kecilnya perusahaan menurut berbagai cara antara lain dengan total aktiva, log size, nilai pasar saham, dan lain - lain. Menurut Analisa (2011), dalam Dewi \& Wirajaya (2013), ukuran perusahaan mempunyai pengaruh yang berbeda terhadap nilai perusahaan suatu perusahaan. Dalam hal ini ukuran perusahaan dilihat dari total assets yang dimiliki oleh perusahaan, yang dapat dipergunakan untuk kegiatan operasional. Berikut perkembangan ukuran perusahaan perusahaan manufaktur sektor industri makanan dan minuman di bursa efek Indonesia .

Tabel 2. Perkembangan Ukuran Perusahaan Pada Perusahaan Manufaktur Sektor Industri Makanan Dan Minuman Di Bursa Efek Indonesia Periode Penelitian 2010-2014

\begin{tabular}{|c|c|c|c|c|c|c|}
\hline \multirow[t]{2}{*}{$\mathrm{No}$} & \multirow[t]{2}{*}{ Nama Perusahaan } & \multicolumn{5}{|c|}{ Tahun } \\
\hline & & 2010 & 2011 & 2012 & 2013 & 2014 \\
\hline 1. & Akasha Wira International Tbk, PT & 26.51 & 26.48 & 26.69 & 26.81 & 26.95 \\
\hline 2. & Delta Djakarta Tbk, PT & 27.29 & 27.27 & 27.34 & 27.49 & 27.62 \\
\hline 3. & Indofood CBP Sukses Makmur Tbk, PT & 30.22 & 30.35 & 30.51 & 30.69 & 30.85 \\
\hline 4. & Indofood Sukses Makmur Tbk, PT & 31.49 & 31.61 & 31.71 & 31.99 & 32.08 \\
\hline 5. & Mayora Indah Tbk, PT & 29.11 & 29.52 & 29.75 & 29.90 & 29.96 \\
\hline 6. & Multi Bintang Indonesia Tbk, PT & 27.76 & 27.83 & 27.77 & 28.21 & 28.43 \\
\hline 7. & Nippon Indosari Corporindo Tbk, PT & 27.07 & 27.36 & 27.82 & 28.23 & 28.39 \\
\hline 8. & Sekar Laut Tbk, PT & 26.02 & 26.09 & 26.24 & 26.43 & 26.53 \\
\hline 9. & Siantar Top Tbk, PT & 27.20 & 27.56 & 27.85 & 28.02 & 28.16 \\
\hline 10. & $\begin{array}{l}\text { Ultrajaya Milk Industry and } \\
\text { Trading Company Tbk, PT }\end{array}$ & 28.33 & 28.41 & 28.52 & 28.66 & 28.70 \\
\hline 11. & $\begin{array}{l}\text { Wilmar Cahaya Indonesia Tbk, PT } \\
\text { (dh. Cahaya Kalbar Tbk, PT }\end{array}$ & 27.47 & 27.44 & 27.66 & 27.70 & 27.88 \\
\hline & Nilai Rata - Rata & 28.04 & 28.17 & 28.35 & 28.56 & 28.69 \\
\hline & Nilai Maksimum & 31.49 & 31.61 & 31.71 & 31.99 & 32.08 \\
\hline & Nilai Minimum & 26.02 & 26.09 & 26.24 & 26.43 & 26.53 \\
\hline
\end{tabular}

Berdasarkan Tabel 2 menunjukkan bahwa nilai rata -rata ukuran perusahaan mengalami kenaikan dari tahun 2010-2014. Itu menunjukkan investor tertarik menanamkan sahamnya di industri makanan dan minuman, sehingga perusahaan yang berada di dalamnya mengalami kenaikan dari segi aktiva perusahaan.

PT. Indofood Sukses Makmur Tbk. mempunyai ukuran perusahaan yang tertinggi selama lima tahun berturut - turut. Ukuran perusahaan tertinggi PT. Indofood Sukses Makmur Tbk. terjadi pada tahun 2014 sebesar 32.08. Hal ini dipengaruhi tingginya nilai total aktiva dari perusahaan PT. Indofood Sukses Makmur Tbk. dari kesebelas sampel perusahaan penelitian dan dari tahun sampel penelitian. Sedangkan perusahaan yang memiliki ukuran perusahaan terendah yaitu PT. Sekar Laut Tbk. di tahun 2010 sebesar 26.02. Hal itu disebabkan total aktiva dari perusahaan PT. Sekar Laut Tbk. rendah dibandingkan aktiva perusahaan lain di industri yang sama. Ukuran perusahaan menggambarkan kapasitas dari suatu perusahaan. Jika perusahaan memiliki ukuran perusahaan tinggi investor akan tertarik untuk menanamkan modalnya. Pada penelitian ini, kesebelas sampel penelitian mayoritas mengalami kenaikan total ukuran perusahaan dari tahun ke tahun. Hal ini menandakan perkembangan ukuran perusahaan dari tahun 2010 - 2014 sangat bagus dan perusahaan sangatlah mampu untuk menarik investor untuk menanamkan modalnya serta citra perusahaan dimata public sangatlah bagus.

\section{Perkembangan Nilai Perusahaan Pada Perusahaan Manufaktur Sektor Industri Makanan Dan Minuman Di Bursa Efek Indonesia}

Nilai perusahaan merupakan persepsi investor terhadap tingkat keberhasilan perusahaan yang sering dikaitkan dengan harga saham. Harga saham yang tinggi membuat nilai perusahaan juga tingi (Moniaga, 2013). Berikut perkembangan nilai perusahaan perusahaan manufaktur sektor industri makanan dan minuman di bursa efek Indonesia : 
Tabel 3. Perkembangan Nilai Perusahaan pada Perusahaan Manufaktur Sektor Industri Makanan dan Minuman Di Bursa Efek Indonesia Periode Penelitian 2010-2014

\begin{tabular}{|c|c|c|c|c|c|c|}
\hline \multirow[t]{2}{*}{ No } & \multirow[t]{2}{*}{ Nama Perusahaan } & \multicolumn{5}{|c|}{ Tahun } \\
\hline & & 2010 & 2011 & 2012 & 2013 & 2014 \\
\hline 1. & Akasha Wira International Tbk, PT & 0.43 & 1.85 & 1.69 & 3.12 & 1.73 \\
\hline 2. & Delta Djakarta Tbk, PT & 1.81 & 2.49 & 3.58 & 5.16 & 5.03 \\
\hline 3. & Indofood CBP Sukses Makmur Tbk, PT & 1.68 & 1.74 & 1.77 & 2.31 & 2.08 \\
\hline 4. & IndofoodSukses Makmur Tbk, PT & 0.88 & 0.90 & 0.84 & 0.85 & 0.81 \\
\hline 5. & Mayora Indah Tbk, PT & 1.19 & 1.29 & 1.51 & 1.79 & 1.69 \\
\hline 6. & Multi Bintang Indonesia Tbk, PT & 0.37 & 0.36 & 0.42 & 0.31 & 0.43 \\
\hline 7. & Nippon Indosari Corporindo Tbk, PT & 3.67 & 3.32 & 2.99 & 11.78 & 2.18 \\
\hline 8. & Sekar Laut Tbk, PT & 0.64 & 0.62 & 0.62 & 0.62 & 0.85 \\
\hline 9. & Siantar Top Tbk, PT & 0.70 & 0.81 & 0.85 & 1.13 & 1.69 \\
\hline 10. & $\begin{array}{l}\text { Ultrajaya Milk Industry and } \\
\text { Trading Company Tbk, PT }\end{array}$ & 1.23 & 1.42 & 1.30 & 3.11 & 3.46 \\
\hline 11. & $\begin{array}{l}\text { Wilmar Cahaya Indonesia Tbk, PT } \\
\text { (dh. Cahaya Kalbar Tbk, PT }\end{array}$ & 0.64 & 0.59 & 0.69 & 0.60 & 0.62 \\
\hline & Nilai Rata - Rata & 1.20 & 1.40 & 1.48 & 2.80 & 1.87 \\
\hline & Nilai Maksi & 3.67 & 3.32 & 3.58 & 11.78 & 5.03 \\
\hline & Nilai Minimum & 0.37 & 0.36 & 0.42 & 0.31 & 0.43 \\
\hline
\end{tabular}

Berdasarkan tabel 3 rata - rata nilai perusahaan meningkat, hanya saja pada tahun 2014 terjadi penurunan. Hal tersebut disebabkan karena pada tahun tahun 2014 perekonomian Indonesia mengalami perlambatan, terjadi penurunan ekspor dan pelemahan ketahanan energi. Penurunan ekspor diakibatkan melemahnya permintaan dari negara - negara mitra dagang utama dan merosotnya harga komoditas ekspor berbasis sumber daya alam.

PT. Nippon Indosari Corporindo Tbk. memiliki nilai perusahaan tertinggi yaitu pada tahun 2013 sebesar 11.78. Hal ini karena PT. Nippon Indosari Corporindo Tbk. memiliki jumlah nilai pasar perusahaan lebih besar dari pada jumlah nilai aset perusahaan. Sedangkan nilai perusahaan terendah adalah PT. Multi Bintang Indonesia Tbk. sebesar 0.31. Hal ini karena PT. Multi Bintang Indonesia Tbk. memiliki jumlah nilai aset perusahaan jauh lebih besar dibanding jumlah nilai pasar perusahaan. Selain itu, tingginya ukuran perusahaan pada tabel 2 tidak menjamin tingginya nilai perusahaan. Hal ini disebabkan sebagian perusahaan di dalam total aktiva perusahaan jumlah aktiva pasif atau aset tidak lancar jauh lebih tinggi dibandingkan jumlah aset lancar, sehingga membuat perusahaan yang memiliki ukuran perusahaan yang tinggi, pada nilai perusahaan sangatlah rendah. Pada penelitian ini nilai perusahaan dihitung menggunakan rumus Tobin's Q. Analisis Tobin's Q jika nilai Tobin's Q > 1 menunjukkan perusahaan memiliki potensi pertumbuhan yang tinggi lebih sekedar dari asetnya. Pada penelitian ini terdapat beberapa perusahaan memiliki nilai Tobin's Q diatas 1, hal ini menunjukkan perusahaan industri makanan dan minuman memiliki potensi pertumbuhan perusahaan yang baik. Tetapi, hal itu tidak diikuti oleh keseluruhan perusahaan, dimana masih ada perusahaan yang nilai perusahaan yang dihitung melalui rumus Tobin's Q jauh dibawah angka 1. Ini berdampak pada keseluruhan perusahaan dibawah industri makanan dan minuman.

\section{Uji Hipotesis}

\section{Analisis Regresi}

Berdasarkan hasil pengujian asumsi klasik yang terdiri dari uji normalitas, uji multikolinearitas, uji autokorelasi dan uji heteroskedastisitas menunjukkan bahwa model yang akan dipakai dalam penelitian ini memenuhi syarat untuk dilakukan regresi berganda dengan baik. Dalam menjawab masalah, tujuan dan untuk melakukan pembuktian hipotesis yang telah ada maka akan dilakukan uji f untuk mengetahui apakah variabel bebas secara simultan berpengaruh terhadap variabel terikat, sedangkan akan dilakukan uji t untuk mengetahui apakah variabel bebas berpengaruh secara signifikan terhadap variavel terikat. Hasil perhitungan analisis linear berganda menggunakan Software IBM SPSS 16.0 dapat dilihat pada tabel berikut : 
Triatmaja, F.

Tabel 4. Hasil Analisis Regresi berganda

Coefficients

\begin{tabular}{|c|c|c|c|c|c|c|}
\hline & \multirow{2}{*}{ Model } & \multicolumn{2}{|c|}{$\begin{array}{c}\text { Unstandardized } \\
\text { Coefficients }\end{array}$} & \multirow{2}{*}{$\begin{array}{c}\text { Standardized } \\
\text { Coefficients }\end{array}$} & \multirow{2}{*}{$\mathrm{T}$} & \multirow{2}{*}{ Sig. } \\
\hline & & B & Std. Error & & & \\
\hline \multirow[t]{3}{*}{1} & (Constanta) & 3.748 & 4.177 & & .897 & .374 \\
\hline & Struktur Modal & -.882 & .400 & -.292 & -2.205 & .032 \\
\hline & Ukuran Perusahaan & -.040 & .147 & -.036 & -.272 & .787 \\
\hline & Multiple $\mathrm{R}$ & \multicolumn{2}{|c|}{$=.087$} & \multicolumn{2}{|c|}{$=2.487$} & \\
\hline & Adjusted $R$ Square & \multicolumn{2}{|c|}{$=.052$} & \multicolumn{2}{|c|}{$\operatorname{Sig} F=.093$} & \\
\hline
\end{tabular}

Dependent Variable : Nilai Perusahaan

Berdasarkan hasil perhitungan pada tabel 4, maka dapat dirumuskan persamaan regresi linear berganda sebagai berikut :

$$
\mathrm{Y}=3.748-0.882 \mathrm{X}_{1}-\log 0.040 \mathrm{X}_{2}
$$

Hasil persamaan regresi linear berganda diatas dapat dijelaskan sebagai berikut :

1. Nilai Konstanta sebesar 3.748 berarti apabila variabel independen dalam penelitian ini diabaikan atau sama dengan nol, maka nilai dari nilai perusahaan sebesar 3.748.

2. Nilai koefisien regresi variabel $X_{1}$ struktur modal bernilai negatif sebesar -0.882 . Berarti apabila nilai variabel lainnya diasumsikan tetap, maka setiap peningkatan struktur modal sebesar 1 akan menurunkan nilai perusahaan sebesar -0.882 .

3. Nilai koefisien regresi variabel $X_{2}$ ukuran perusahaan bernilai negatif sebesar -0.040 . Berarti apabila nilai variabel lainnya diasumsikan tetap, maka setiap peningkatan ukuran perusahaan sebesar 1 akan menurunkan nilai perusahaan sebesar -0.040 .

\section{Uji Signifikansi Simultan (Uji F)}

Uji hipotesis secara simultan (uji F) digunakan untuk mengetahui apakah keseluruhan variabel independen mempunyai pengaruh terhadapvariabel dependen. Hasil perhitungan model regresi linear berganda untuk uji signifikansi simultan (uji F) dapat dilihat pada tabel di bawah ini :

Tabel 5. Hasil Uji Signifikansi Simultan (Uji F)

\begin{tabular}{|l|c|c|c|c|l|}
\hline \multicolumn{1}{|c|}{ Model } & $\begin{array}{c}\text { Sum of } \\
\text { Squares }\end{array}$ & Df & Mean Square & $\mathrm{F}$ & Sig. \\
\hline 1 Regression & 15.150 & 2 & 7.575 & 2.487 & $.093^{\mathrm{a}}$ \\
Residual & 158.396 & 52 & 3.046 & & \\
Total & 173.546 & 54 & & & \\
\hline
\end{tabular}

a. Predictors: (Constant), Ukuran Perusahaan (X2), Struktur Modal

(X1)

b. Dependent Variable: Nilai Perusahaan (Y)

\section{Pengujian hipotesis 1}

1. $\mathrm{H}_{1}$ : Struktur modal dan ukuran perusahan berpengaruh terhadap nilai perusahaan.

2. Hasil uji F pada tabel 5 menunjukan signifikansi sebesar $0.093 \leq 0.10$. Hal ini menunjukkan uji $F$ menolak Ho dan menerima Ha. Sehingga dapat dikatakan bahwa variabel independen yaitu 
struktur modal dan ukuran perusahaan mempunyai pengaruh secara simultan terhadap variabel dependen yaitu nilai perusahaan. Dengan demikian hipotesis pertama diterima.

\section{Uji Signifikansi Parsial (Uji t)}

Uji signifikansi parsial (uji t) dimaksudkan untuk menguji signifikansi pengaruh masing masing variabel independen terhadap variabel dependen. Pengujian hipotesis pengaruh dari kedua variabel independen yaitu struktur modal dan ukuran perusahaan terhadap variabel dependen yaitu nilai perusahaan sebagai berikut :

\section{Pengujian hipotesis 2}

1. $\mathrm{H}_{2}$ : Struktur modal berpengaruh terhadap nilai perusahaan.

2. Berdasarkan tabel 4 variabel independen yaitu struktur modal $\left(\mathrm{X}_{1}\right)$, diperoleh nilai signifikansi sebesar 0.032. Hal ini menunjukkan nilai signifikansi lebih rendah dari 0.10 , sehingga struktur modal $\left(\mathrm{X}_{1}\right)$ berpengaruh terhadap nilai perusahaan $(\mathrm{Y})$. Dengan demikian hipotesis kedua diterima.

\section{Pengujian hipotesis 3}

1. $\mathrm{H}_{3}$ : Ukuran perusahaan berpengaruh terhadap nilai perusahaan.

2. Berdasarkan tabel 4 variabel independen yaitu ukuran perusahaan $\left(\mathrm{X}_{2}\right)$, diperoleh nilai signifikansi sebesar 0.787. hal ini menunjukkan nilai signifikansi diatas 0.10 , sehingga ukuran perusahaan $\left(\mathrm{X}_{2}\right)$ tidak berpengaruh terhadap nilai perusahaan $(\mathrm{Y})$. Dengan demikian hipotesis ketiga ditolak.

Tabel 6. Hasil Uji Signifikansi Parsial (Uji t)

Coefficients

\begin{tabular}{|c|c|c|c|c|c|c|}
\hline & \multirow{2}{*}{ Model } & \multicolumn{2}{|c|}{$\begin{array}{c}\text { Unstandardized } \\
\text { Coefficients }\end{array}$} & \multirow{2}{*}{$\begin{array}{c}\begin{array}{c}\text { Standardized } \\
\text { Coefficients }\end{array} \\
\text { Beta }\end{array}$} & \multirow[t]{2}{*}{$\mathrm{T}$} & \multirow{2}{*}{ Sig. } \\
\hline & & B & Std. Error & & & \\
\hline \multirow[t]{3}{*}{1} & $($ Constanta) & 3.748 & 4.177 & & .897 & .374 \\
\hline & Struktur Modal & -.882 & .400 & -.292 & -2.205 & .032 \\
\hline & Ukuran Perusahaan & -.040 & .147 & -.036 & -.272 & .787 \\
\hline
\end{tabular}

Dependent Variable : Nilai Perusahaan

Selanjutnya, guna memperjelas hasil pengujian seluruh hipotesis penelitian, maka hasil pengujian seluruh hipotesis penelitian ditampilkan pada tabel 7 :

Tabel 7. Hasil Uji Hipotesis

\begin{tabular}{ccccc}
\hline Hipotesis & $\begin{array}{c}\text { Nilai } \\
\text { Signifikansi }\end{array}$ & $\begin{array}{c}\text { Standar } \\
\text { Signifikansi }\end{array}$ & Keterangan \\
\hline $\mathrm{H}_{1}$ & $\begin{array}{c}\text { Struktur modal dan ukuran } \\
\text { perusahaan tidak } \\
\text { berpengaruh secara simultan } \\
\text { terhadap nilai perusahaan }\end{array}$ & 0.093 & 0.10 & $\begin{array}{c}\text { Diterima / } \\
\text { Signifikan }\end{array}$ \\
\hline $\mathrm{H}_{2}$ & $\begin{array}{c}\text { Struktur modal berpengaruh } \\
\text { secara parsial terhadap nilai } \\
\text { perusahaan }\end{array}$ & 0.032 & 0.10 & $\begin{array}{c}\text { Diterima / } \\
\text { Signifikan }\end{array}$ \\
\hline $\mathrm{H}_{3}$ & $\begin{array}{c}\text { Ukuran perusahaan tidak } \\
\text { berpengaruh secara parsial } \\
\text { terhadap nilai perusahaan }\end{array}$ & 0.787 & 0.10 & $\begin{array}{c}\text { Ditolak / } \\
\text { Tidak } \\
\text { signifikan }\end{array}$ \\
\hline
\end{tabular}




\section{Pembahasan Hasil Penelitian}

\section{Pengaruh Struktur Modal Dan Ukuran Perusahaan Terhadap Nilai Perusahaan}

Berdasarkan hasil pengujian hipotesis diperoleh struktur modal dan ukuran perusahaan berpengaruh secara simultan terhadap nilai perusahaan pada perusahaan manufaktur sektor industri makanan dan minuman. Pada tabel 5 pengujian secara simultan diperoleh tingkat signifikansi sebesar 0.093, nilai ini dibawah standar signifikansi $\alpha(0.10)$.

Penelitian ini sejalan dengan Prasetia dkk (2014), Dewi dan Wirajaya (2013), serta Pratiwi dkk (2016), yang didalam penelitiannya menemukan struktur modal dan ukuran perusahaan berpengaruh terhadap nilai perusahaan. Dalam penelitian yang dilakukan oleh Prasetia dkk (2014), menyatakan pihak manajemen perusahaan dan pihak terkait lainnya memandang pentingnya melihat kondisi struktur modal dan ukuran perusahaan secara bersama dalam mengukur nilai perusahaan. Penelitian dari Dewi dan Wirajaya (2013), mengatakan penentuan struktur modal dengan menggunakan hutang pada tingkat tertentu sebagai sumber pendanaannya dapat meningkatkan nilai perusahaan. Sedangkan dari ukuran perusahaan menunjukkan bahwa perusahaan dengan skala yang besar akan dengan mudah memperoleh hutang terkait dengan tingkat kepercayaan kreditur terhadap perusahaan - perusahaan besar. Penelitian dari Pratiwi dkk (2016), mengungkapkan jika struktur modal mengalami peningkatan, maka nilai perusahaan juga akan mengalami peningkatan.

Berdasarkan hasil uji koefisien determinasi $\left(\mathrm{R}^{2}\right)$, dapat diketahui bahwa nilai $\left(\mathrm{R}^{2}\right)$ sebesar 0.052 atau $5.2 \%$. Sehingga variabel dependen yaitu nilai perusahaan dapat dijelaskan oleh kedua variabel independen yaitu struktur modal dan ukuran perusahaan sebesar 5.2\%. Sedangkan sisanya $94.8 \%$ berarti bahwa nilai perusahaan dipengaruhi dipengaruhi oleh variabel lain diluar dari penelitian ini seperti profitabilitas dan price earning ratio.

\section{Pengaruh Struktur Modal Terhadap Nilai Perusahaan}

Hasil pengujian hipotesis diperoleh struktur modal berpengaruh negatif terhadap nilai perusahaan pada perusahaan manufaktur sektor industri makanan dan minuman yang terdaftar di bursa efek Indonesia. Hal ini sesuai tabel 5.8 pengujian secara parsial diperoleh tingkat signifikansi struktur modal yaitu 0.032 , berada di bawah standar signifikansi $\alpha(0.10)$, serta nilai Beta -0.882 . Berdasarkan data yang diperoleh rata - rata struktur modal berada di kisaran nilai optimal yaitu tahun 2010 sebesar 1.00, tahun 2011 sebesar 0.86. tahun 2012 sebesar 1.01, tahun 2013 sebesar 0.90 dan tahun 2014 sebesar 1.13. Hal ini sesuai dengan Kasmir (2012), dalam Pratiwi dkk, (2016), nilai optimum Debt to Equity Ratio (DER) berada diantara 85\% - 100\% dikatakan baik, sedangkan nilai optimum di bawah 85\% dikatakan kurang baik. Rata - rata struktur modal pada tahun 2014 berada di atas nilai optimal yaitu 1.13, mengakibatkan menurunnya rata - rata nilai perusahaan pada tahun 2014 yaitu 1.87 dari sebelumnya pada tahun 2013 sebesar 2.80. Hal ini sesuai dengan Trade-off theory seperti yang dikutip oleh Dewi dan Wirajaya (2013), menjelaskan bahwa jika posisi struktur modal berada dibawah titik optimal maka setiap penambahan hutang akan meningkatkan nilai perusahaan. Sebaliknya,jika posisi struktur modal berada diatas titik optimal maka setiap penambahan hutang akan menurunkan nilai perusahaan.

Hasil uji yang telah diperoleh pada uji-t yaitu struktur modal berpengaruh negatif terhadap nilai perusahaan, dapat diartikan bahwa dalam struktur modal penggunaan hutang sebagai sumber pendanaan modal sudah sangat tinggi dibandingkan penggunaan modal sendiri sebagai sumber dana perusahaan. Kebanyakan perusahaan mengandalkan hutang sebagai sumber pendanaannya karena beberapa faktor diantaranya keseimbangan penghematan pajak dan biaya kesulitan pajak. Trade-off theory optimal menggambarkan masalah keseimbangan biaya dengan nilai perlindungan pajak bunga yang dihasilkan oleh pinjaman. Untuk itu, perusahaan hendaknya menyeimbangkan antara besarnya hutang dengan modal sendiri. Hal ini dikarenakan masing - masing kebijakan memiliki kelebihan masing - masing.

Hal inilah yang terjadi pada perusahaan pada penelitian ini. Penggunaan hutang yang tinggi akan berdampak pada semakin besar beban terhadap pihak eksternal (kreditur). Peningkatan beban terhadap pihak eksternal akan menunjukkan sumber modal perusahaan bergantung pada pihak lain di luar perusahaan tersebut, serta risiko yang dihadapi akan semakin besar. Dalam pengelolaan, manajemen harus bisa membuat kegiatan operasional perusahaan jauh lebih baik untuk mendapatkan keuntungan yang lebih guna menutup hutang yang tinggi. Apabila dalam kegiatan operasional perusahaan mengalami kendala yang cukup berarti dan mengakibatkan kerugian, maka perusahaan 
tidak dapat membayar semua hutang yang dimilikinya. Investor tidak akan tertarik kepada perusahaan dan mengakibatkan perusahaan mengalami penurunan dari segi nilai perusahaan.

Pada perusahaan manufaktor sektor industri makanan dan minuman dalam penelitian ini tergolong perusahaan besar, dimana perusahaan besar seharusnya menggunakan sumber dana internal yaitu modal sendiri untuk membiayai perusahaan tersebut. Karena dengan menggunakan modal sendiri dalam membiayai perusahaan dapat mengurangi risiko dan bisa menarik investor untuk menanamkan modalnya. Hal ini sesuai dengan pendapat dari Roses, dkk., (2002), dalam Sumiati (2011), di dalam pecking order theory menjelaskan manajer perusahaan dihadapkan pada dua aturan dalam menentukan struktur modal pembiayaan perusahaan yaitu menggunakan sumber pendanaan pembiayaan internal terlebih dahulu dan menerbitkan surat berharga yang paling aman terlebih dahulu. Dengan demikian, ketika perusahaan dihadapkan dengan masalah pembiayaan, di dalam pecking order theory perusahaan sebaiknya menggunakan sumber modal sendiri terlebih dahulu, baru menggunakan hutang dan terakhir menerbitkan saham baru.

Hasil penelitian ini didukung oleh penelitian dari Dewi \& Wirajaya (2013), Pratiwi, dkk., (2016), dan Moniaga (2013). Namun, hasil temuan ini berbeda dengan Prasetia, dkk., (2014), yang menemukan struktur modal tidak berpengaruh terhadap nilai perusahaan.

\section{Pengaruh Ukuran Perusahaan Terhadap Nilai Perusahaan}

Hasil pengujian hipotesis diperoleh ukuran perusahaan tidak berpengaruh terhadap nilai perusahaan. Hal ini sesuai tabel 8 pengujian secara parsial diperoleh tingkat signifikansi ukuran perusahaan yaitu 0.787 , berada di atas standar signifikansi $\alpha(0.10)$. Total aset yang tinggi dari kesebelas sampel dalam penelitian ini menghasilkan total ukuran perusahaan yang tinggi pula, namun dalam perhitungan didapatkan tingginya ukuran perusahaan tidak diikuti oleh peningkatan nilai perusahaan. Rendahnya nilai perusahaan disebabkan total aset yang tinggi namun aset tersebut merupakan aset pasif. Hal ini dapat di lihat dari total aset tidak lancar jauh lebih tinggi dibandingkan total aset lancar. Ini mengindikasikan tingginya total aset pada suatu perusahaan bisa menjadi penyebab turunnya nilai perusahaan.

Hasil penelitian ini didukung oleh Dewi dan Wirajaya (2013), dalam penelitiannya mengungkapkan ukuran perusahaan tidak mempunyai pengaruh terhadap nilai perusahaan. Namun, bertolak belakang dengan hasil penelitian dari Prasetyorini (2013), dan Pratiwi, dkk., (2016), yang menemukan ukuran perusahaan berpengaruh signifikan terhadap nilai perusahaan.

\section{KESIMPULAN DAN SARAN}

\section{Kesimpulan}

Berdasarkan pembahasan diatas dapat disimpulkan sebagai berikut :

1. Struktur modal dan ukuran perusahaan berpengaruh secara simultan dan signifikan terhadap variabel dependen yaitu nilai perusahaan. Artinya dilihat dari nilai $\mathrm{R}^{2}$ yaitu 5.2\% secara serempak struktur modal dan ukuran perusahaan mempunyai pengaruh terhadap nilai perusahaan. Sedangkan sisanya $94.8 \%$ nilai perusahaan dipengaruhi oleh variabel lain diluar dari penelitian ini seperti profitabilitas dan price earning ratio.

2. Struktur modal berpengaruh negatif dan signifikan terhadap variabel dependen yaitu nilai perusahaan. Artinya bahwa dalam struktur modal penggunaan hutang sebagai sumber pendanaan modal sudah sangat tinggi dibandingkan penggunaan modal sendiri sebagai sumber dana perusahaan.

3. Ukuran perusahaan tidak berpengaruh secara parsial dan tidak signifikan terhadap variabel dependen yaitu nilai perusahaan. Artinya rendahnya nilai perusahaan disebabkan total aset yang tinggi namun aset tersebut merupakan aset pasif. Hal ini dapat di lihat dari total aset tidak lancar jauh lebih tinggi dibandingkan total aset lancar. Ini mengindikasikan tingginya total aset pada suatu perusahaan bisa menjadi penyebab turunnya nilai perusahaan.

\section{Saran}

Berdasarkan hasil penelitian yang dilakukan, penulis akan memberikan saran sebagai berikut : 
1. Bagi perusahaan, sebaiknya dalam pendanaan perusahaan sebaiknya menggunakan modal sendiri terlebih dahulu guna menghindari risiko yang bisa menyebabkan perusahaan mengalami kerugian. Apabila perusahaan harus menggunakan hutang dalam pendanaan perusahaan, sebaiknya dalam kegiatan operasional manajemen harus bisa mengelola perusahaan dengan baik dan menghasilkan keuntungan yang lebih untuk melunasi hutang yang telah ada.

2. Bagi akademisi, keterbatasan dalam penelitian ini hendaknya lebih disempurnakan dengan menambah sektor industri lainnya yang terdaftar di Bursa Efek Indonesia.

3. Bagi penelitian selanjutnya disarankan untuk memperluas variabel independen yang memiliki pengaruh lebih besar terhadap nilai perusahaan sebagai variabel dependennya.

\section{REFERENSI}

Brigham, E. F. \& Joel F. Houston, (2001). Manajemen Keuangan, Buku Kedua, Edisi Kedelapan. Jakarta: Erlangga.

Dewi, A. S. M. \& Wirajaya, A. (2013). Pengaruh Struktur Modal, Profitabilitas dan Ukuran Perusahaan terhadap Nilai Perusahaan. E-Jurnal Akuntansi Universitas Udayana, 4(2), 358372.

Hidayat, R. (2015). Pengaruh Likuiditas, Profitabilitas, Struktur Aktiva Dan Ukuran Perusahaan Terhadap Struktur Modal Pada Perusahaan Manufaktur Sektor Makanan Dan Minuman Yang Terdaftar Di Bursa Efek Indonesia (BEI). Skripsi Fakultas Ekonomi Universitas Tadulako, Palu.

Husnan, S. (2000). Manajemen Keuangan Teori Dan Penerapan (Keputusan Jangka Panjang), Edisi Keempat, Cetakan Keempat. Yogyakarta: BPFE-Yogyakarta.

Moniaga, F. (2013). Struktur Modal, Profitabilitas Dan Struktur Biaya Terhadap Nilai Perusahaan Industri Keramik, Porcelen Dan Kaca Periode 2007-2011. Jurnal EMBA, 1(4), 433-442.

Permanasari, W. I. (2010). Pengaruh Kepemilikan Manajemen, Kepemilikan Institusional Dan Corporate Social Responsibility Terhadap Nilai Perusahaan. Skripsi Fakultas Ekonomi Universitas Diponegoro, Semarang.

Prasetia, T. E., Parengkuan, T. \& Ivone S. Saerang, (2014). Struktur modal, Ukuran Perusahaan dan Risiko Perusahaan Terhadap Nilai Perusahaan Otomotif Yang Terdaftar Di BEI. Jurnal EMBA, 2(2), 879-889.

Prasetyorini, B. F. (2013). Pengaruh ukuran perusahaan, leverage, price earning ratio dan profitabilitas terhadap nilai perusahaan. Jurnal Ilmu Manajemen, 1(1).

Pratiwi, N. P. Y., Yudiatmaja, Fridayana, \& Suwendra, I. W. (2016). Pengaruh Struktur Modal Dan Ukuran Perusahaan Terhadap Nilai Perusahaan. Jurnal Manajemen, 4.

Sartono, R. A. (2012). Manajemen Keuangan Teori Dan Aplikasi, Edisi Keempat, Cetakan Keenam. Yogyakarta: BPFE-Yogyakarta.

Sumiati. (2011). Kekuatan Pasar, Struktur Modal dan Nilai Perusahaan (Studi Pada Perusahaan Manufaktur Yang Terdaftar Di Bursa Efek Indonesia). Disertasi Fakultas Ekonomi dan Bisnis Universitas Brawijaya, Malang. 